\title{
Pit-1 $\beta$ reduces transcription and CREB-binding protein recruitment in a DNA context-dependent manner
}

\author{
A L Ferry, D M Locasto, L B Meszaros, J C Bailey, M D Jonsen', \\ K Brodsky ${ }^{1}$, C J Hoon ${ }^{1}$, A Gutierrez-Hartmann ${ }^{1}$ and \\ $S$ E Diamond
}

\begin{abstract}
Department of Physiology, University of Kentucky College of Medicine, Lexington, Kentucky 40536, USA
${ }^{1}$ Departments of Medicine and of Biochemistry and Molecular Genetics, University of Colorado Health Sciences Center, Denver, Colorado 80262, USA

(Requests for offprints should be addressed to S E Diamond, Department of Physiology, University of Kentucky College of Medicine, 800 Rose Street, Lexington, KY 40536-0298; Email: sediam0@uky.edu)

(C J Hoon is now at Martek Biosciences Corporation, 4909 Nautilus Court North, \#208, Boulder, Colorado 80301, USA)
\end{abstract}

\begin{abstract}
Many transcription factors are expressed as multiple isoforms with distinct effects on the regulation of gene expression, and the functional consequences of structural differences between transcription factor isoforms may allow for precise control of gene expression. The pituitary transcription factor isoforms Pit- 1 and Pit- $1 \beta$ differentially regulate anterior pituitary hormone gene expression. Pit-1 is required for the development of and appropriate hormone expression by anterior pituitary somatotrophs and lactotrophs. Pit- $1 \beta$ differs structurally from Pit-1 by the splice-insertion of the 26 -residue $\beta$-domain in the transactivation domain, and it differs functionally from Pit-1 in that it represses expression of the prolactin promoter in a cell-type specific manner. In order to identify signal and
\end{abstract}

promoter context requirements for repression by Pit- $1 \beta$, we examined its function in the presence of physiological regulatory signals as well as wild-type and mutant Pit-1dependent target promoters. Here, we demonstrate that Pit-1 $\beta$ impairs recruitment of cAMP response elementbinding protein (CREB)-binding protein to the promoters that it represses. In addition, we show that repression of target promoter activity, reduction in promoter histone acetylation, and decrease of CREB-binding protein recruitment all depend on promoter context. These findings provide a mechanism for promoter-specific repression by Pit-1 $\beta$.

Journal of Endocrinology (2005) 185, 173-185

\section{Introduction}

Most transcription factors are members of extended families defined by conserved structural motifs, typically in the DNA- and ligand-binding domains, yet they differ in other domains, especially the transactivation domain (TAD). These proteins can have distinct effects on the regulation of target gene expression, tumorigenesis, or the effectiveness of pharmacological approaches to cancer treatment (e.g. c-Jun vs v-Jun (Jurdic et al. 1995, Huguier et al. 1998); estrogen receptor- $\alpha$ vs $-\beta$ (Chu et al. 2000); glucocorticoid receptor- $\alpha$ vs $-\beta$ (Longui et al. 2000); and progesterone receptor A vs B (Richer et al. 1998, McGowan \& Clarke 1999)). The pituitary-specific transcription factor isoforms Pit-1 (recently renamed POU1F1) and Pit-1 $\beta$ differentially regulate anterior pituitary hormone gene expression. Pit- 1 and Pit- $1 \beta$ differ only by the insertion of the 26-amino acid (AA) $\beta$-domain in the Pit-1 TAD; yet they have diametrically opposed actions with regard to prolactin (PRL) expression in pituitary cells.
Pit-1, a pituitary-specific member of the POU homeodomain family of transcription factors, is required for the normal growth and development of three anterior pituitary cell types: somatotrophs, lactotrophs and thyrotrophs. Pit-1 is necessary for the proper temporal and spatial expression of their respective hormones - PRL, growth hormone $(\mathrm{GH})$ and thyroid stimulating hormone $\beta$-subunit (TSH $\beta$ ) - as well as for the expression of the thyroid hormone receptor, GH-releasing hormone receptor and Pit-1 itself (Dolle et al. 1990, Simmons et al. 1990, Treier \& Rosenfeld 1996, Wood et al. 1996, Pickett \& Gutierrez-Hartmann 1997, Ryan \& Rosenfeld 1997).

The transcriptional activity of Pit- 1 is determined partly by a balance of interactions with the coactivator cAMP response element-binding protein (CREB)-binding protein $(\mathrm{CBP})$ and an $\mathrm{N}-\mathrm{CoR} / \mathrm{mSin} 3$-containing corepressor (Xu et al. 1998). Indeed, Pit-1 can increase histone acetylation and alter the chromatin structure of the PRL promoter (Diamond \& Gutierrez-Hartmann 2000, Kievit \& Maurer 2005). Pit-1 transduces Ras, cAMP/protein 
kinase A (PKA), and growth factor/protein kinase C, activating signals to the rat PRL promoter, but phosphorylation of Pit-1 is not required for signal mediation of any of these (Keech et al. 1992, Fischberg et al. 1994, Howard \& Maurer 1994, Okimura et al. 1994).

Pit-1 transduces growth factor signals to the rat PRL promoter through the three most proximal DNA binding sites for Pit-1, FP I-III, and transduces Ras signaling through the more distal FP IV (Keech et al. 1992, Liang et al. 1992, Bradford et al. 1995, Rajnarayan et al. 1995). Pit-1 functionally interacts with Oct-1 (Diamond et al. 1999), as well as pituitary CREB (Fliss et al. 1999), to reconstitute PKA-enhanced PRL promoter expression. Pit-1 interacts with Ets-1 to transduce Ras signaling, and Pit-1 and Ets-1 synergistically increase PRL promoter activity in HeLa non-pituitary cells (Bradford et al. 1995, 1997).

The Pit-1-Ets-1 interaction is quite specific, and neither Ets-2 nor Pit-1 $\beta$ is able to take part in this interaction (Bradford et al. 1997). The synergy domain on Ets-1 maps to the region III TAD (Augustijn et al. 2002), and each of the two exons of the Pit-1 TAD has recently has been shown to contribute differing activities to the functional synergy between Pit-1 and Ets-1 and to transduce the Ras response (Duval et al. 2003). Specifically, the first TAD exon modulates Pit-1's ability to synergize with Ets-1 in reconstitution systems, while the second TAD exon acts as a tissue-specific transducer of Ras signaling.

Pit- $1 \beta$ arises from use of an alternate $3^{\prime}$ splice acceptor at the end of the first intron (Konzak \& Moore 1992, Morris et al. 1992, Theill et al. 1992), which inserts the 26 AA $\beta$-domain at position 48 in the TAD. The $\beta$-domain dictates a range of isoform-specific transcriptional properties, such that Pit-1 $\beta$ acts as a repressor of transcription from the PRL promoter in pituitary somatolactotrophs, which express both PRL and GH, and $\alpha$-TSH thyrotrophs (Konzak \& Moore 1992, Morris et al. 1992, Theill et al. 1992, Haugen et al. 1994), and blocks Ras signaling to the PRL promoter in somatolactotroph (Conrad et al. 1994, Bradford et al. 1995). The $\beta$-domain acts as a transcription switch motif (Diamond et al. 1999) that dictates active repression of the PRL promoter by modifying the acetylation state of the PRL promoter (Diamond \& Gutierrez-Hartmann 2000).

The AA sequence of the $\beta$-domain is conserved across the vertebrates (Konzak \& Moore 1992, Morris et al. 1992, Ono \& Takayama 1992, Theill et al. 1992, Wong et al. 1992, Delhase et al. 1995) and dictates the dominantnegative properties of Pit-1 $\beta$ (Diamond et al. 1999). Analysis of the $\beta$-domain itself has revealed that two regions consisting of five hydrophobic AAs (leucine 7 , isoleucine 8 , tyrosine 17 , phenylalanine 18 and methionine 20) are required for repression of the PRL promoter (Diamond \& Gutierrez-Hartmann 2000).

The transcriptional activity of Pit-1 is dictated by the DNA-binding-induced conformation of Pit-1 on different promoters (Scully et al. 2000). These results suggest that the $\beta$-domain might function by modulating the conformational changes induced in Pit- 1 by promoter context or by different signals impinging on Pit-1 target promoters.

In this manuscript, we describe the promoter-, sequence- and signal-specificity of transcriptional repression by Pit- $1 \beta$. We demonstrate that Pit-1 $\beta$ impairs recruitment of CBP to promoters that it represses, and that repression of target promoter activity, and reduction in promoter histone acetylation, depend on promoter context. Specifically, we demonstrate that repression by Pit-1 $\beta$ is independent of the mechanism that determines Ras signaling to the PRL promoter. We show that Pit-1 $\beta$ represses the PRL and GH promoters, which rely on Pit-1 to recruit CBP, but it does not repress its own promoter, which relies on CREB to recruit CBP. Our demonstration that Pit- $1 \beta$ reduces CBP recruitment to repressed promoters provides a mechanism for promoter-specific repression by Pit $-1 \beta$.

\section{Materials and Methods}

\section{Cell culture}

Monolayer cultures of $\mathrm{GH}_{3}$ and $\mathrm{GH}_{4}$ rat pituitary tumor cells (Tashiian et al. 1968) were maintained in Dulbecco's modified Eagle's medium, 20\% fetal bovine serum and $50 \mu \mathrm{g} / \mathrm{ml}$ penicillin and streptomycin at $37^{\circ} \mathrm{C}$ in $5 \% \mathrm{CO}_{2}$. The medium was changed $16-18 \mathrm{~h}$ before each transfection. Cells used for transfection were harvested at approximately 60-80\% confluence using $0 \cdot 05 \%$ trypsin and $0.5 \mathrm{mM}$ EDTA. Forskolin (FSK) was used at $9 \mu \mathrm{M}$ in DMSO.

\section{Plasmids}

Plasmids $\mathrm{pA}_{3} \mathrm{PRLluc:firefly} \mathrm{luciferase}$ driven by the proximal $(-425)$ rat PRL promoter and $\mathrm{pA}_{3}$ GHluc:firefly luciferase driven by the proximal $(-593)$ rat GH promoter have been described previously (Conrad \& Gutierrez-Hartmann 1992). Plasmid $\mathrm{pA}_{3}$ Pit-1 luc:firefly luciferase driven by the proximal $(-200)$ rat Pit-1 promoter was constructed as follows: the -200 to +1 of the Pit-1 promoter was amplified from p-200 GHF1-CAT plasmid (the generous gift of M Karin, UCSD, San Diego, CA, USA) using the following primers, CGGTACCgtccc acttattgacg and CCAAGCTTggeggctctgagge, and the resulting fragment cloned into pCR2·1 (Invitrogen).

The fragments were confirmed by sequencing, then were isolated and cloned into the HindIII-KpnI sites upstream of the pA3-luc plasmid (Maxwell et al. 1989) plasmid pSV Ras: H-Ras valine 12 mutant, driven by the SV40 early promoter; and plasmids pRSV influenza hemaglutinin (HA) epitope Pit-1, HA Pit-1 $\beta$ and $\beta$-globin (Tokitou et al. 1999), driven by the RSV promoter (Diamond \& Gutierrez-Hartmann 2000). 
Five mutant $\mathrm{pA}_{3}-425 \mathrm{PRL}$ plasmids were used: (i) plasmid $\mathrm{pA}_{3} \mathrm{mFP}$ IV, a mutation of -200 to -195 from ATTAAT to GTCGAC; (ii) plasmid $\mathrm{pA}_{3} \mathrm{EBS}$, which contains a mutation from -214 to -209 - the sequence was changed from AAGGAA to an Xho1 site, CTCGAC; (iii) plasmid $\mathrm{pA}_{3} \operatorname{PRLLuc}(-425) \mathrm{mFP}$ III, a mutation of -160 to -155 , from GAATAT to CTCGAG; (iv) plasmid $\mathrm{pA}_{3}$ PRLLuc $(-425) \mathrm{mFP}$ II, a mutation of -128 to -123 , from GTTTAA to CTCGAG; and (v) plasmid $\mathrm{pA}_{3} \operatorname{PRLLuc}(-425) \mathrm{mFP}$ I, a mutation of -52 to -47 , from ATTCAT to CTCGAG (Jackson et al. 1992, Keech et al. 1992, Bradford et al. 1996).

\section{Transfection}

DNA was introduced into $\mathrm{HeLa}, \mathrm{GH}_{3}$ or $\mathrm{GH}_{4}$ cells by electroporation as follows. Approximately $2-3 \times 10^{6}$ enzymatically dispersed cells were mixed with plasmid DNA in a sterile gene-pulse chamber and exposed to a controlled electrical field of $500 \mu \mathrm{F}$ at $220 \mathrm{~V}$, as described previously (Diamond et al. 1999, Diamond \& Gutierrez-Hartmann 2000). Cells from individual transfections then were maintained in Dulbecco's modified Eagle's medium, 15\% horse serum, $2.5 \%$ fetal bovine serum and $50 \mu \mathrm{g} / \mathrm{ml}$ of penicillin and streptomycin, at $37^{\circ} \mathrm{C}$.

A 1:3 Pit-1:Pit-1 $\beta$ plasmid DNA ratio that results in equal levels of protein expression was used (Diamond et al. 1999, Diamond \& Gutierrez-Hartmann 2000). The nonspecific effect of the RSV promoters upon transcription factor availability was controlled by including amounts of pRSV $\beta$-globin plasmid DNA in all assays to render the total pRSV DNA concentration constant. Twenty-five nanograms of plasmid pRLC Renilla were included as an internal control for all transfections. Cells from individual transfections were maintained for $24 \mathrm{~h}$.

\section{Luciferase assays}

Transient transfections were performed in triplicate, in at least three separate experiments. After incubation for $24 \mathrm{~h}$, cells were harvested and assayed, using the Dual Luciferase Reporter Assay System (Promega) and a Monolight 3010 Luminometer (Analytical Luminescence Laboratories, San Diego, CA, USA). Firefly luciferase light units for each transfection are normalized for Renilla luciferase light units. Results are expressed as mean fold activation of the PRL promoter \pm S.E.M. for at least three experiments, in triplicate. Fishers protected least significant differences (one-way ANOVA between groups, followed by twotailed Student's $t$-tests) was used to calculate significance of differences between multiple conditions.

\section{Western blot analysis of $H A$-tagged Pit-1 proteins}

Transient transfections using pRSV HA Pit- 1 and Pit- $1 \beta$ were performed as above. Three aliquots of cells were pooled and harvested with PBS containing 3 mM EDTA, pelleted and resuspended in $5 \times$ Lowry loading buffer and passed through a $25 \mathrm{G}$ needle seven times. Equal volumes of each extract were separated on 15\% SDS polyacrylamide gels and transferred to Immobilon-P PVDF membranes (Millipore, Bedford, MA, USA). The HA-tagged Pit-1 proteins were detected with a mouse monoclonal anti-HA horseradish peroxidase-conjugated antibody (Roche Diagnostics, Indianapolis, IN, USA) and ECL Advance media (Amersham Biosciences). Dilutions of 1:1000 of the anti-HA monoclonal antibody were used.

\section{Chromatin immunoprecipitation studies}

Chromatin immunoprecipitation (ChIP) assays were performed according to the protocol for the AcetylHistone H4 ChIP Assay Kit (Upstate Biotechnology, Lake Placid, NY, USA), as described previously (Diamond \& Gutierrez-Hartmann 2000, Lambert \& Nordeen 2003). Transient transfections were performed as above. Twentyfour hours after transfection, $1.6 \times 10^{7} \mathrm{GH}_{3}$ cells were cross-linked by addition of formaldehyde into the medium at a final concentration of $1 \%$ and incubated for $15 \mathrm{~min}$ at room temperature.

Cells were washed with ice-cold PBS and resuspended in a $500 \mu \mathrm{l}$ ChIP lysis buffer (1\% SDS, $10 \mathrm{mM}$ EDTA, $50 \mathrm{mM}$ Tris- $\mathrm{HCl}, \mathrm{pH} 8 \cdot 0$, with protease inhibitors). The lysates were sonicated with a Branson Sonifier 450 (Branson Ultrasonics Corp., Danbury, CT, USA) at power setting 2, with three, $10 \mathrm{~s}$ pulses at duty cycle 90 , and diluted to $3 \mathrm{ml}$ with a ChIP dilution buffer (0.01\% SDS, $1 \cdot 1 \%$ Triton X-100, $1 \cdot 2 \mathrm{mM}$ EDTA, $16 \cdot 7 \mathrm{mM}$ Tris-HCl, $\mathrm{pH} 8 \cdot 0,167 \mathrm{mM} \mathrm{NaCl}$ ). One milliliter of each sample was precleared by incubating with $80 \mu$ l Protein A beads agarose for $30 \mathrm{~min}$ at $4{ }^{\circ} \mathrm{C}$ with rotation. Five microliters of anti-acetyl histone $\mathrm{H} 4$ antibody (Upstate Biotechnology) or anti-CBP antibody (Santa Cruz Biotechnology, Santa Cruz, CA. USA) were added, and immunoprecipitation was done overnight at $4{ }^{\circ} \mathrm{C}$, with rotation.

Immune complexes were collected with $60 \mu$ Protein A agarose and washed once with $1 \mathrm{ml}$ each of the following buffers in sequence: low-salt wash buffer $(0 \cdot 1 \%$ SDS, $1 \%$ Triton X-100, 2 mM EDTA, $20 \mathrm{mM}$ Tris- $\mathrm{HCl}$, $\mathrm{pH} 8 \cdot 0$, $150 \mathrm{mM} \mathrm{NaCl})$, high-salt wash buffer $(0 \cdot 1 \%$ SDS, $1 \%$ Triton X-100, 2 mM EDTA, 20 mM Tris-HCl, pH 8.0, $1500 \mathrm{mM} \mathrm{NaCl}), \mathrm{LiCl}$ wash buffer $(250 \mathrm{mM} \mathrm{LiCl}, 1 \%$ NP-40, 1\% sodium deoxycholate, $1 \mathrm{mM}$ EDTA, $10 \mathrm{mM}$ Tris- $\mathrm{HCl}, \mathrm{pH} 8 \cdot 0)$. Then they were washed twice with $10 \mathrm{mM}$ Tris- $\mathrm{HCl}, \mathrm{pH} 8 \cdot 0,1 \mathrm{mM}$ EDTA.

Immune complexes were eluted, cross-links were reversed by heating at $65^{\circ} \mathrm{C}$, and extracts were subjected to proteinase $\mathrm{K}$ treatment to eliminate protein. DNA was recovered by phenol-chloroform extraction, followed by ethanol precipitation, and used as a template for PCR (30 cycles), using pA3-425 PRL Luc promoter-specific, commercially synthesized deoxyoligonucleotides (Gibco/ BRL) that contain a PRL promoter-specific sequence, 
GACTCAAGATGTCAGTCAGC, and a luciferasespecific sequence, GCCTTTCTTTATGTTTTTGGC.

In addition, internal control PCR reactions were performed with pSV 40 plasmid-specific, commercially synthesized deoxyoligonucleotides (Gibco/BRL) that contain SV40 promoter-specific sequences, GCATCTCAAT TAGTCAGC and GGAATAGCTCAGAGGCCGAG. Control reactions were performed to ensure that all PCR assays took place in the linear range of response to input DNA. PCR products were separated by agarose gel electrophoresis, and bands were imaged and quantified (relative to a $50 \mathrm{ng}$ control band) on a Foto/Eclipse-CCD (Fotodyne Corp., Hartland, WI, USA) and Gel Documentation System with NIH image (Bethesda, MD, USA). Densitometric units were normalized to those of the SV40 control in the presence of wild-type (WT) PRL promoter.

\section{Results}

Pit-1 $\beta$ blocks multiple signaling pathways to the PRL promoter

We have previously demonstrated that the $\beta$-domain insertion converts Pit-1 from an activator to a repressor of the PRL promoter (Conrad et al. 1994, Bradford et al. 1995). Moreover, we have shown that the AA sequence of the $\beta$-domain dictates this repression and that the activity of a histone deacetylase is required (Diamond et al. 1999, Diamond \& Gutierrez-Hartmann 2000). If the $\beta$-domain simply alters the balance between Pit-1-associated histone acetylation vs deacetylation in a simple manner, one would expect that Pit-1 $\beta$ would block the PRL promoter, regardless of signals impinging upon it, and repress all Pit-1 target promoters. Signal- or promoter-specificity of repression would suggest that repression requires the array of transcription cofactors involved in the particular signal or promoter context, and thus it may involve an alteration in the mechanism of signaling.

In order to test whether Pit-1 $\beta$ can repress the PRL promoter in the presence of signals other than oncogenic Ras, we examined the effects of Pit-1 $1 \beta$ in the presence of an activated cAMP/PKA pathway. This signaling pathway is independent of, and actually antagonistic toward, that of Ras (Conrad \& Gutierrez-Hartmann 1992). Pit-1 and Pit-1 $\beta$ were introduced into $\mathrm{GH}_{3}$ pituitary somatolactotroph cells by electroporation in the presence of a PRL promoter-driven luciferase reporter and either pSV Ras or FSK, an activator of the PKA signaling pathway (Conrad \& Gutierrez-Hartmann 1992) (Fig. 1A). We used a 3:1 ratio of Pit-1 $\beta$ :Pit-1 plasmid DNA that we previously have shown to result in comparable levels of protein expression (Diamond et al. 1999, Diamond \& Gutierrez-Hartmann 2000) (Fig. 1B).

Ras and FSK increased PRL promoter activity $12-$ and 9-fold respectively (data not shown). Co-transfection with Pit-1 enhanced the activity of the PRL promoter by more than $74 \%$ in the presence of no signal, by $64 \%$ in the presence of oncogenic Ras and by $37 \%$ in the presence of FSK. Co-transfection of the Pit- $1 \beta$ isoform not only failed to enhance the activity of the PRL promoter but actually reduced it by $40-54 \%$. Thus, Pit- $1 \beta$ can repress PRL promoter activity in the presence of two independent signaling pathways (Ras and FSK) of the PRL promoter.

\section{Pit-1 $1 \beta$ shows promoter selectivity for repression}

In order to test whether Pit-1 $\beta$ would repress multiple Pit-1 target promoters, Pit- 1 and Pit- $1 \beta$ were introduced into $\mathrm{GH}_{4}$ pituitary somatolactotroph cells by electroporation in the presence of luciferase reporter constructs regulated by the proximal region of either the rat PRL promoter, GH promoter or Pit-1 promoter (Fig. 2). For each promoter, the firefly luciferase gene was placed under the control of a region that previously has been shown sufficient to confer cell-type specific gene expression in transient transfection experiments: the -425 to $+65 \mathrm{bp}$ of the $5^{\prime}$ flanking region of the PRL promoter (Camper et al. 1985, Gutierrez-Hartmann et al. 1987, Elsholtz 1992, Bradford et al. 1997), the -593 to +65 bp of the $5^{\prime}$ flanking region of the GH promoter (Flug et al. 1987, Ye et al. 1988, Schaufele 1996, Palomino et al. 1998), and the -200 to $+1 \mathrm{bp}$ of the $5^{\prime}$ flanking region of the Pit-1 promoter (Chen et al. 1990, McCormick et al. 1990, 1991) respectively.

Co-transfection of Pit-1 enhanced the PRL promoter activity by $26 \%$, and co-transfection of the Pit- $1 \beta$ isoform reduced activity by approximately 67\% (Fig. 3A). Co-transfection with Pit-1 had no significant effect on the GH promoter activity, and co-transfection of the Pit-1 $\beta$ isoform reduced activity by $61 \%$. Co-transfection with either Pit-1 or Pit-1 $\beta$ had no significant effect on the Pit-1 promoter activity. As documented previously, co-transfection with Pit-1 did little to enhance target promoter activation in pituitary cells, but Pit-1 $\beta$ showed great differences in action on the different target promoters. Similar results were seen in $\mathrm{GH}_{3}$ pituitary cells (data not shown). These data show that the $\beta$-domain confers repression to a subset of Pit-1 target promoters.

A trivial explanation for lack of repression of the Pit-1 promoter by Pit-1 $\beta$ would be that Pit- $1 \beta$ could not interact with the proximal Pit-1 promoter and thus could not repress its activity in somatolactotrophs. We previously have demonstrated that Pit-1 $\beta$ displays cell-type specificity in its ability to repress the PRL promoter in pituitary cells, and it actually activates the PRL promoter in HeLa non-pituitary cells (Diamond et al. 1999). Thus, we used HeLa non-pituitary cells, which lack endogenous Pit-1 expression, in order to demonstrate that Pit-1 and Pit-1 $\beta$ could indeed interact with and activate all three target promoters in non-pituitary cells.

HA-tagged Pit-1 and HA-tagged Pit-1 $\beta$ were introduced into HeLa non-pituitary cells by electroporation in 


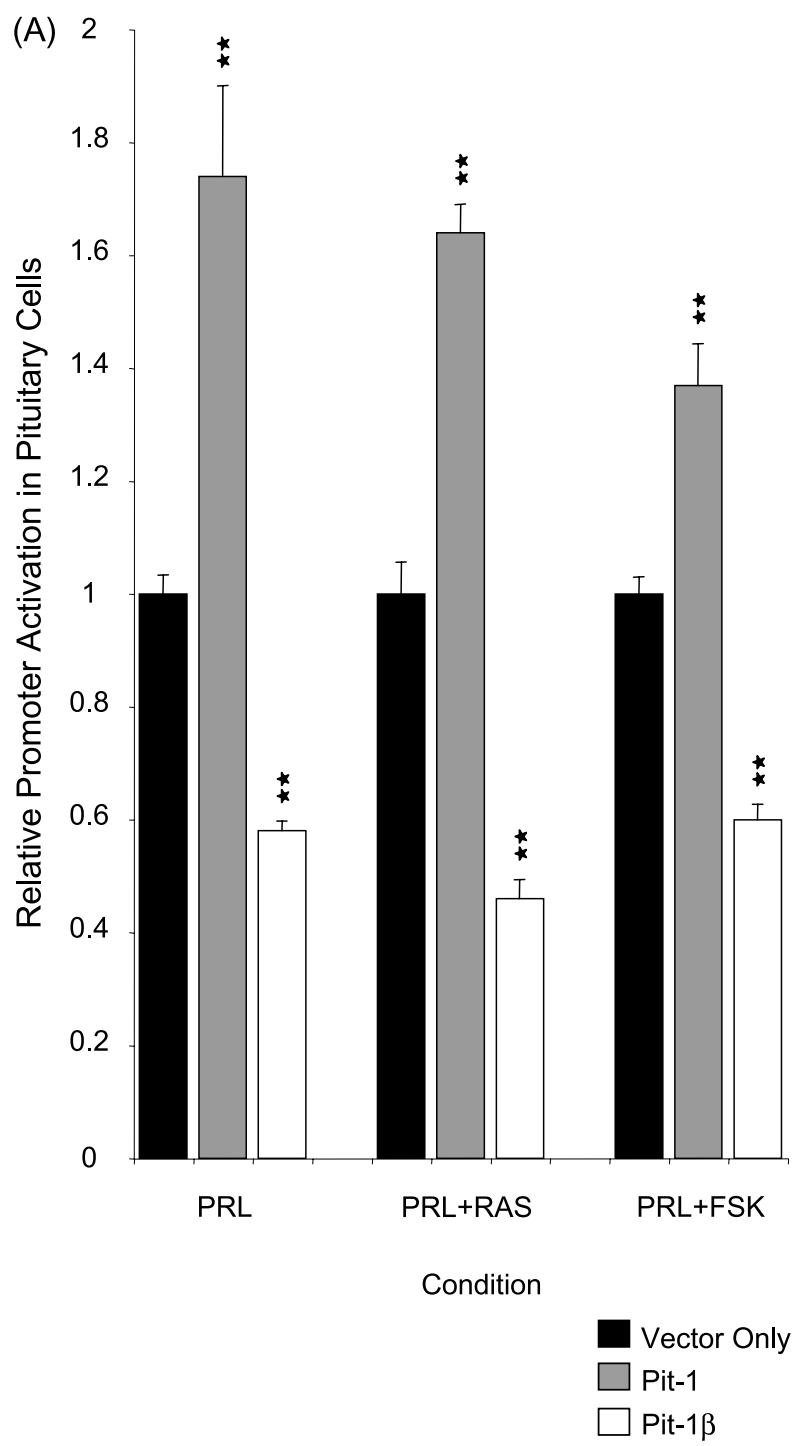

(B)
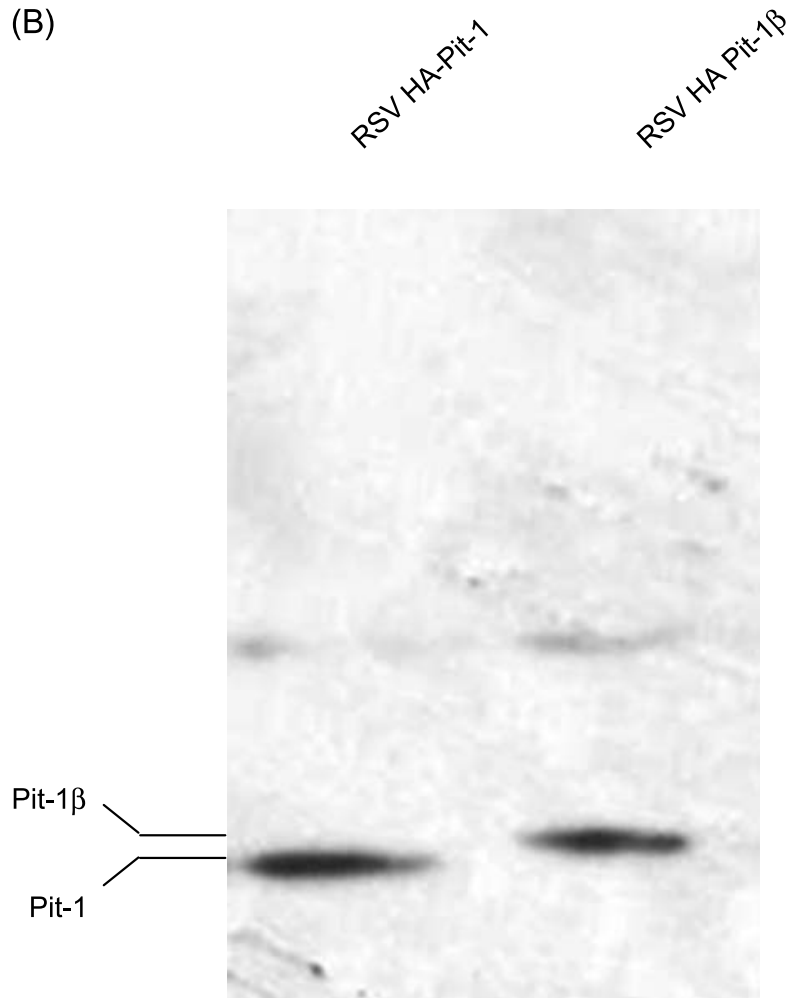

Pit-1

Figure 1 Pit- $1 \beta$ blocks multiple signaling pathways to the PRL promoter. (A) Effects of Pit- 1 and Pit- $1 \beta$ on activation of the PRL promoter by the Ras and PKA signaling pathways in $\mathrm{GH}_{3}$ cells. Plasmid pA3 PRL luc $-425(3 \mu \mathrm{g})$ and combinations of pSV Ras $(2 \mu \mathrm{g})$, pRSV HA Pit-1 $(10 \mu \mathrm{g})$ and pRSV HA Pit-1 $\beta(30 \mu \mathrm{g})$ were introduced into $4 \times 10^{6} \mathrm{GH}_{3}$ pituitary cells by electroporation. Vehicle (DMSO) or $9 \mu \mathrm{M}$ FSK in DMSO was added for the last $3 \mathrm{~h}$ of incubation. Total RSV and SV40 promoter amounts were maintained constant with pRSV $\beta$-globin and pSV40 DNA. After $24 \mathrm{~h}$, cells were harvested and total light units were measured. Starred bars are significantly different from vector only: ${ }^{* *} P<0 \cdot 01$. (B) Expression levels of Pit- 1 and Pit- $1 \beta$. Plasmids pRSV HA Pit- 1 (10 $\left.\mu \mathrm{g}\right)$ and pRSV HA Pit-1 $\beta(30 \mu \mathrm{g})$ were introduced into $4 \times 10^{6} \mathrm{GH}_{3}$ pituitary cells by electroporation. After $24 \mathrm{~h}$, cells were harvested and analyzed by SDS-PAGE and Western blot (See Materials and Methods).

the presence of luciferase reporter constructs regulated by either the proximal regions of the PRL promoter, the GH promoter, or the Pit-1 promoter (Fig. 3B). Pit-1 and Pit-1 $\beta$ activated the PRL promoter by $66-$ and $100-$ fold respectively. Pit-1 and Pit-1 $\beta$ activated the GH promoter by 3 - and 10 -fold respectively, and the Pit-1 promoter by 3- and 21-fold respectively. Of note, the GH and Pit-1 promoters were activated to similar extents by both Pit-1 and Pit-1 $\beta$. These data demonstrate that the failure of
Pit-1 $\beta$ to repress the Pit-1 promoter was not due to an inability to interact with or activate that promoter, but rather to a specific loss of ability to repress the promoter.

\section{Pit-1 $\beta$ shows promoter context requirements for repression}

Target promoter-specific repression by Pit- $1 \beta$ suggests that specific promoter elements, and thus, specific transcription cofactors brought to these elements, might be 

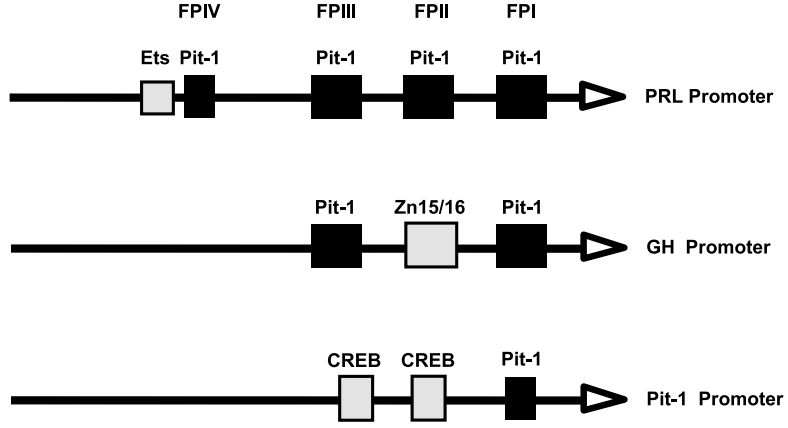

Figure 2 Three Pit- 1 target promoters. The proximal PRL, GH and Pit-1 promoters are shown (not to scale). Pit-1 binding sites are shown as black squares, and other transcription factor binding sites appear as grey squares. Mutations of FP I II, III and IV, as well as the EBS of the RRE were tested (See Materials and Methods).

required for repression. In order to test this hypothesis, Pit-1 and Pit-1 $\beta$ were introduced into $\mathrm{GH}_{3}$ pituitary somatolactotroph cells by electroporation in the presence of a series of mutant PRL promoter-reporter constructs with previously characterized substitutions for four Pit-1 binding sites, FP I, FP II, FP III and FP IV in the proximal PRL promoter (Fig. 2) (Jackson et al. 1992, Keech et al. 1992, Bradford et al. 1996, Kievit \& Maurer 2005).

The FP IV Pit-1 binding site forms part of a composite Ras response element (RRE), together with a binding site for Ets-1 (Bradford et al. 1996). The failure of Pit-1 $\beta$ to interact functionally with Ets-1 in non-pituitary cells had led to a model of Pit-1 $\beta$ repression in which repression of PRL promoter activity takes place in the context of this composite FP IV/Ets-binding site (EBS), required for optimal Ras signaling to the PRL promoter (Bradford et al. 2000).

Mutation of the FP I, FP II, FP III and FP IV elements decreased PRL promoter activity by 14-, 6-, 5- and 3-fold respectively (data not shown). As documented previously, co-transfection with the Pit-1 $\beta$ isoform reduced the response of the WT PRL promoter in the presence of oncogenic Ras (Fig. 4A) by 37\%. Co-transfection with the Pit-1 $\beta$ isoform did not reduce, but rather enhanced, the response of the mutant (m) FP I, II and III PRL promoters in the presence of oncogenic Ras by 67, 42 and 55\% respectively. However, Pit-1 $\beta$ did repress the response of the $\mathrm{mFP}$ IV reporter in the presence of oncogenic Ras by 46\%. These data demonstrate that FP I, FP II and FP III, but not FP IV, are necessary for repression. Thus, specific sequence requirements exist for repression by the Pit- $1 \beta$ isoform.

The demonstration that the Pit-1 binding site in the RRE is unnecessary for repression suggests that previous models of Pit-1 $\beta$ repression that involve interactions with Ets- 1 and require the composite FP IV RRE in the PRL promoter (Bradford et al. 1995, 1996, 1997) are incorrect. To further test this model, we tested the ability of a mutation of the FP IV-proximal EBS that prevents Ets-1 binding (Bradford et al. 1996) to block repression by the Pit-1 $\beta$ isoform (Fig. 4B).

Mutation of the EBS element, like that of the FP IV element, reduced PRL promoter activity 3-fold (data not shown). In the presence of oncogenic Ras, co-transfection with the Pit- 1 isoform activated the WT PRL promoter by $2 \cdot 2$-fold, and co-transfection with the Pit- $1 \beta$ isoform reduced the response of the WT PRL promoter by $45 \%$. Co-transfection with the Pit-1 isoform shows no significant effect on the mFP IV promoter, and co-transfection with the Pit-1 $\beta$ isoform reduced the response of the mFP IV promoter by $55 \%$, as Fig. $4 \mathrm{~A}$ also shows. Co-transfection with the Pit-1 isoform activated the mEBS PRL promoter by $2 \cdot 3$-fold, and co-transfection with the Pit- $1 \beta$ isoform reduced the response of the mEBS promoter by $58 \%$. These data demonstrate that neither element of the FP IV composite Pit-1/EBS is required for repression by the Pit-1 $\beta$ isoform.

In order to test whether the DNA-context dependence of repression by Pit- $1 \beta$ shows signal specificity, we introduced Pit-1 and Pit-1 $\beta$ into GH3 pituitary somatolactotroph cells by electroporation in the presence of the FP I, FP II, FP III and FP IV mutant PRL promoterreporter constructs in the presence of FSK (Fig. 5). Mutation of the FP I, FP II, FP III and FP IV elements decreased PRL promoter activity by 10-, 7-, 3- and 3-fold respectively (data not shown).

Co-transfection with the Pit-1 $\beta$ isoform reduced the response of the WT PRL promoter in the presence of FSK by $64 \%$. Co-transfection with the Pit-1 $\beta$ isoform did not reduce, but rather enhanced, the response of the mFP I, II and III PRL promoters in the presence of FSK 7, 21 and $26 \%$ respectively, similar to the $37 \%$ increase in the presence of Pit-1 (Fig. 1A). However, Pit-1 $\beta$ did repress the response of the mFP IV reporter in the presence of FSK by $77 \%$. Similar results were seen in $\mathrm{GH}_{4}$ pituitary cells (data not shown). These data demonstrate that the DNA-context requirements for repression are the same in the presence of FSK or Ras.

\section{Pit-1 $\beta$ shows promoter-context requirements for alterations in target promoter histone acetylation}

We previously have shown that Pit- $1 \beta$ represses PRL promoter activity by altering the histone acetylation state of its target promoter (Diamond \& Gutierrez-Hartmann 2000). In order to test whether the DNA sequence requirements for promoter repression were reflected in the sequence requirements for reduction of histone acetylation, HA-tagged Pit-1 and HA-tagged Pit- $1 \beta$ were introduced into $\mathrm{GH}_{3}$ pituitary cells by electroporation in the presence of the mFP I, mFP II, mFP III or mFP IV PRL promoters (Fig. 6). In addition, we used the SV40 promoter of the pSV plasmid as a control promoter, to demonstrate that Pit-1 $\beta$-dependent changes in histone 


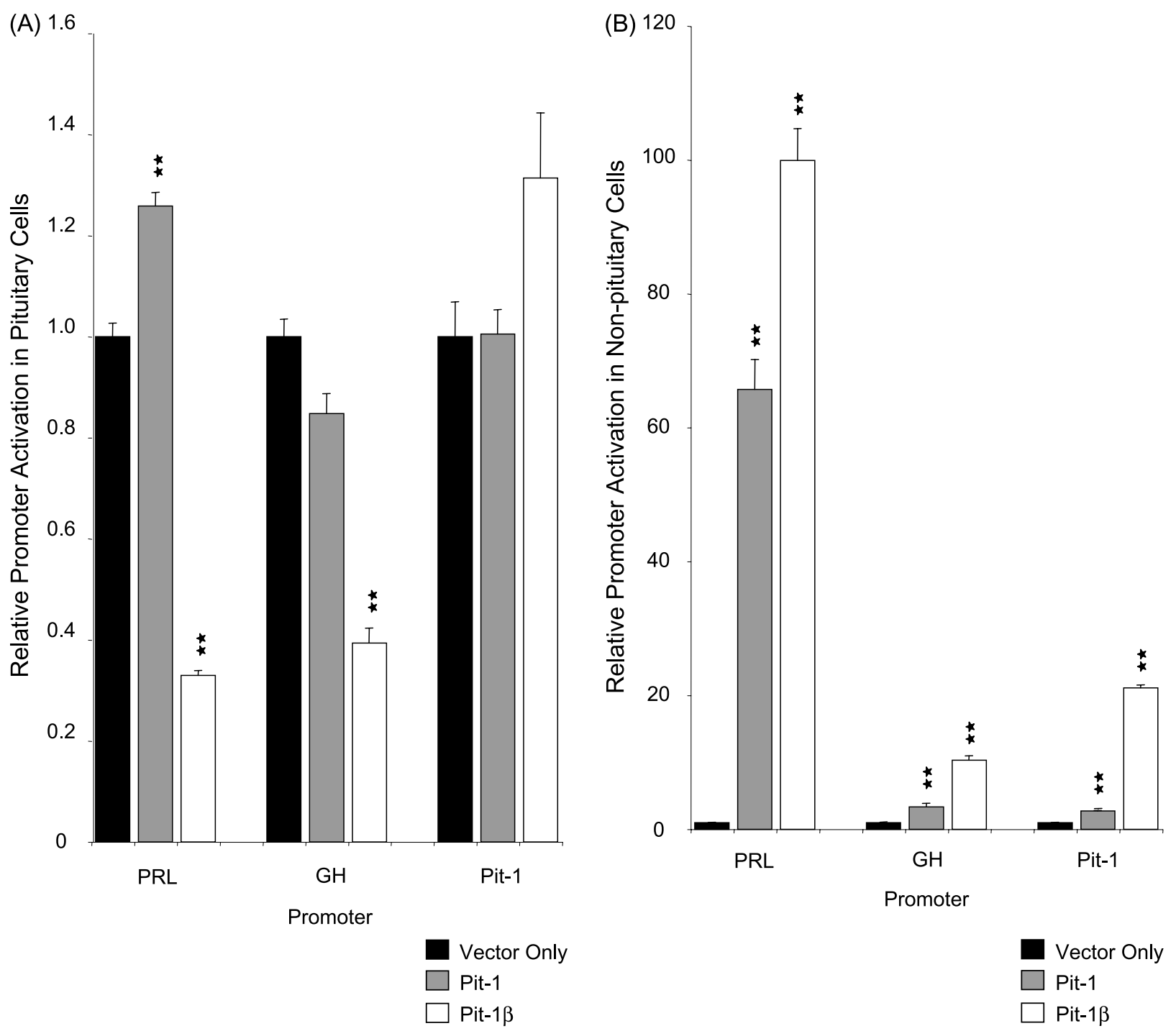

Figure 3 Pit- $1 \beta$ shows promoter selectivity for repression. (A) Effects of Pit- 1 and Pit-1 $\beta$ constructs on activation of the target promoters PRL, $\mathrm{GH}$ and Pit- 1 promoters in $\mathrm{GH}_{4}$ cells. Combinations $(5 \mu \mathrm{g})$ of plasmids pA3 PRL luc $-425, \mathrm{pA} 3 \mathrm{GH}_{\text {luc }}-593$ or pA 3 Pit-1 luc -200 , together with pRSV HA Pit-1 $(4 \mu \mathrm{g})$ and pRSV HA Pit- $1 \beta(15 \mu \mathrm{g})$, were introduced into $4 \times 10^{6} \mathrm{GH}_{4}$ pituitary cells by electroporation. Total RSV promoter amounts were maintained constant with pRSV $\beta$-globin DNA. After $24 \mathrm{~h}$, cells were harvested and total light units were measured. Starred bars are significantly different from vector only: ${ }^{*} P<0 \cdot 01$. (B) Effects of Pit- 1 and Pit- $1 \beta$ constructs on activation of the target promoters PRL, GH and Pit-1 promoters in HeLa cells. Combinations $(5 \mu \mathrm{g})$ of plasmids pA3 PRL luc $-425, \mathrm{pA} 3 \mathrm{GH}$ luc and $\mathrm{pA}_{3}$ GH luc -593 , together with pRSV HA Pit-1 $(4 \mu \mathrm{g})$ and pRSV HA Pit-1 $\beta$ (14 $\left.\mu \mathrm{g}\right)$, were introduced into $4 \times 10^{6} \mathrm{HeLa}$ non-pituitary cells by electroporation. Total RSV promoter amounts were maintained constant with pRSV $\beta$-globin DNA. After $24 \mathrm{~h}$, cells were harvested and total light units were measured. Starred bars are significantly different from vector only: ${ }^{* *} P<0 \cdot 01$.

deacetylation were specific for the proximal PRL promoter and not global changes in histone deacetylation. The SV40 promoter is activated by CBP (Tabakin-Fix et al. 2004) and is not affected by Pit-1 or Pit-1 $\beta$ (Eckel et al. 2003).

As documented previously, co-transfection with Pit-1 increased the acetylation level of the WT, mFP II and mFP III PRL promoters and had no effect on the acetylation level of the mFP I and $\mathrm{m}$ FP IV promoters in the presence of oncogenic Ras. Co-transfection with Pit-1 $\beta$ reduced the acetylation level of the WT and mFP IV PRL promoters but not of the mFP I, mFP II and mFP III PRL promoters. Indeed, Pit-1 $\beta$ significantly increased $(67 \%)$ the acetylation level of the $\mathrm{mFP}$ III promoter. These data suggest that the same sequence requirements that dictate repression by the Pit-1 $\beta$ isoform also dictate its ability to alter histone acetylation of the PRL promoter. 

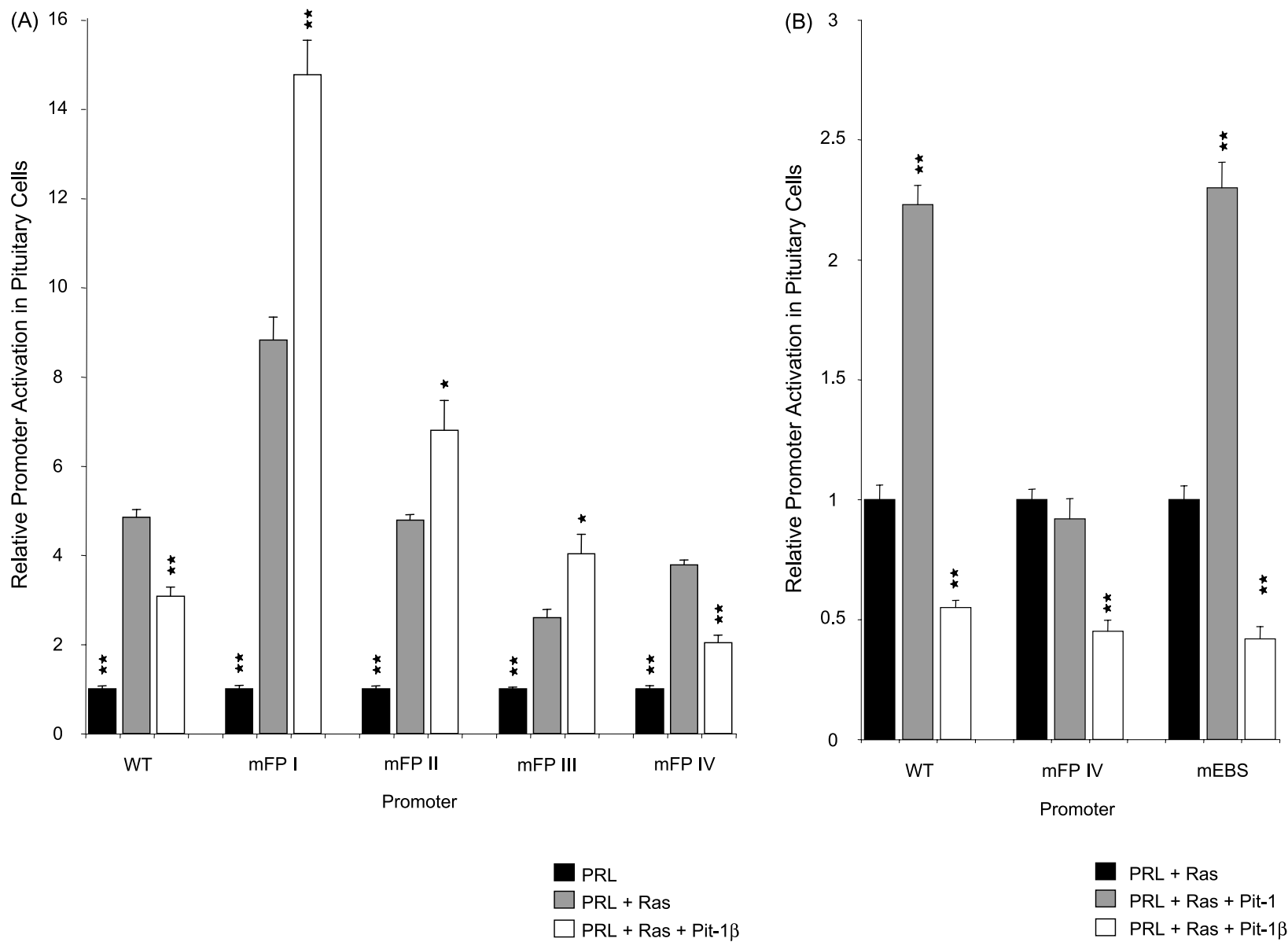

Figure 4 Pit- $1 \beta$ shows promoter-context requirements for repression. (A) Effects of Pit-1 $\beta$ on activation of mutant PRL promoter in the Ras signaling pathway in $\mathrm{GH}_{3}$ cells. Combinations $(3 \mu \mathrm{g})$ of plasmids $\mathrm{pA}_{3}-\mathrm{pA}_{3}$ PRLLuc $(-425), \mathrm{pA}_{3}$ PRLLuc $(-425) \mathrm{mFP}$ IV, $\mathrm{pA}_{3}$ PRLLuc $(-425) \mathrm{mFP}$ III, $\mathrm{pA}_{3} \operatorname{PRLLuc}(-425) \mathrm{mFP}$ II, and $\mathrm{pA}_{3}$ PRLLuc $(-425) \mathrm{mFP}$ I together with combinations of pSV Ras $(2 \mu \mathrm{g})$ and pRSV HA Pit-1 $\beta(30 \mu \mathrm{g})$, were introduced into $4 \times 10^{6} \mathrm{GH}_{3}$ pituitary cells by electroporation. Total RSV and SV 40 promoter amounts were maintained constant with pRSV $\beta$-globin and pSV40 DNA. After $24 \mathrm{~h}$, cells were harvested and total light units were measured. Starred bars are significantly different from vector only+Ras: ${ }^{*} P<0 \cdot 01 ;{ }^{*} P<0 \cdot 05$. (B) Effects of Pit- 1 and Pit- $1 \beta$ on activation of PRL promoters with mutant RREs by the Ras signaling pathway in $\mathrm{GH}_{3}$ cells. Combinations $(3 \mu \mathrm{g})$ of plasmids $\left.\mathrm{pA}_{3}-\mathrm{pA}_{3} \mathrm{PRLLuC}-425\right)$, $\mathrm{pA}_{3}$ PRLLuc $(-425) \mathrm{mFP}$ IV and $\mathrm{pA}_{3} \mathrm{EBS}$ together with combinations of pSV Ras $(2 \mu \mathrm{g})$, pRSV HA Pit- $1(10 \mu \mathrm{g})$ and pRSV HA Pit- $1 \beta$ $(30 \mu \mathrm{g})$, were introduced into $4 \times 10^{6} \mathrm{GH}_{3}$ pituitary cells by electroporation. Total RSV and SV40 promoter amounts were maintained constant with pRSV $\beta$-globin and pSV40 DNA. After $24 \mathrm{~h}$, cells were harvested and total light units were measured. Starred bars are significantly different from vector only+Ras: ${ }^{*} P<0 \cdot 01$.

In order to test a model in which Pit-1 $\beta$ can reduce recruitment of CBP to the PRL promoter, we examined the level of CBP recruitment to the PRL, GH and Pit-1 promoters in $\mathrm{GH}_{3}$ pituitary cells. HA-tagged Pit-1 and HA-tagged Pit- $1 \beta$ were introduced into $\mathrm{GH}_{3}$ pituitary cells by electroporation in the presence of the mFP I, mFP II, mFP III or mFP IV PRL promoters (Fig. 7). In addition, we used the SV40 promoter, which CBP can activate (Tabakin-Fix et al. 2004), as a control to demonstrate that the Pit-1 $\beta$-dependent decrease in CBP recruitment is not global, but rather specific for the proximal PRL promoter. Co-transfection with Pit-1 had no significant effect on the recruitment of CBP to the PRL, GH or Pit-1 promoters in $\mathrm{GH}_{3}$ pituitary cells. However, co-transfection with Pit-1 $\beta$ significantly reduced recruitment of CBP to the PRL and GH promoters but not to the Pit-1 promoter.

\section{Discussion}

The influence of promoter context on the transcriptional activity of Pit-1 itself (Scully et al. 2000) suggests that repression by Pit-1 $\beta$ also might be modulated by promoter context. This hypothesis would predict that the activity of the $\beta$-domain itself might be affected by either promoter 


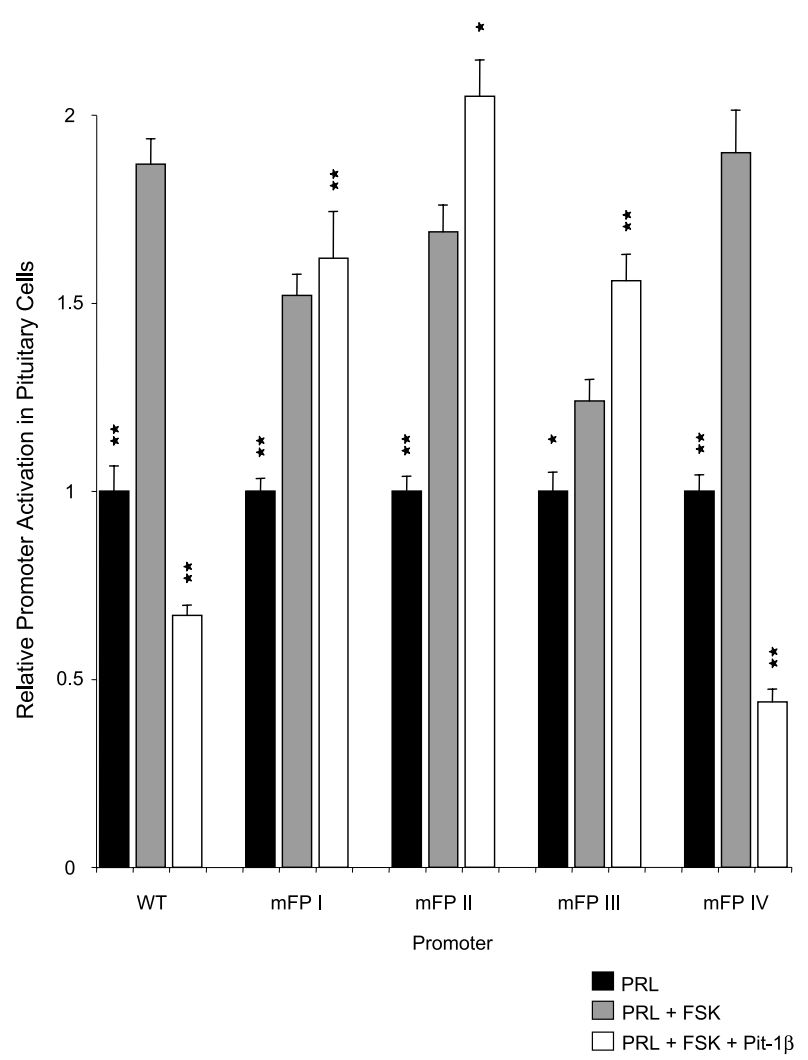

Figure 5 Pit- $1 \beta$ shows no signal specificity in its promoter-context requirements for repression. Effects of Pit-1 $\beta$ on activation of mutant PRL promoter by the cAMP signaling pathway in $\mathrm{GH}_{3}$ cells. Combinations ( $3 \mu \mathrm{g}$ ) of plasmids $\mathrm{pA}_{3}-\mathrm{pA}_{3}$ PRLLuc $(-425)$, $\mathrm{pA}_{3}$ PRLLuc $(-425) \mathrm{mFP}$ IV, $\mathrm{pA}_{3}$ PRLLuc $(-425) \mathrm{mFP}$ III, $\mathrm{pA}_{3}$ PRLLuc $(-425) \mathrm{mFP}$ II and $\mathrm{pA}_{3} \operatorname{PRLLuc}(-425) \mathrm{mFP}$ I, together with combinations of pRSV HA Pit- $1 \beta(30 \mu \mathrm{g})$, were introduced into $4 \times 10^{6} \mathrm{GH}_{3}$ pituitary cells by electroporation. Total RSV promoter amounts were maintained constant with pRSV $\beta$-globin. After $24 \mathrm{~h}$, cells were harvested and total light units were measured. Starred bars are significantly different from vector only+FSK: ${ }^{* *} P<0 \cdot 01 ;{ }^{*} P<0 \cdot 05$.

context or by differing signaling pathways. Promoter context has been shown to modulate the transcriptional activity of many transcription factors, either through direct effects of DNA sequence elements on protein conformation (reviewed in Lefstin \& Yamamoto 1998) or through interaction with neighboring cofactors. Here, we demonstrate that Pit-1 $\beta$ impairs CBP recruitment to promoters that it represses. In addition, we show that repression of target promoter activity, reduction in promoter histone acetylation, and decrease of CBP recruitment all depend on promoter context.

Our experiments demonstrate that Pit-1 $\beta$ represses target promoters in a promoter-context-dependent manner. The ability of Pit- $1 \beta$ to repress PRL promoter activity in the presence or absence of Ras or FSK (Fig. 1A) is consistent with our previous findings that the mechanism for isoform-specific regulation involves the alteration of histone acetylation, which should inhibit promoter activity broadly. The promoter selectivity of repression by Pit- $1 \beta$ in our experiments (Fig. 3A) suggests that repression depends on promoter elements present in the proximal $\mathrm{GH}$ and PRL promoters but absent in the proximal Pit-1 promoter.

The ability of Pit- $1 \beta$ to activate the Pit-1 promoter in parallel experiments in HeLa non-pituitary cells (Fig. 3B) allows us to rule out the possibility that the lack of repression by Pit- $1 \beta$ of the Pit- 1 promoter could be due to an inability of Pit-1 $\beta$ to bind to and modulate the Pit-1 promoter. We have previously have demonstrated that Pit-1 $\beta$ acts as a repressor in a pituitary-specific manner and actually activates PRL promoter activity in HeLa nonpituitary cells (Diamond \& Gutierrez-Hartmann 1996, 2000).

What are the promoter-specific attributes that provide the contextual information to Pit- $1 \beta$ ? We investigated this question with a series of mutant PRL promoter constructs, each of which is defective in one of the principal transcription factor binding motifs present in the PRL promoter (Figs 4 and 5). Previous models of Pit- $1 \beta$ repression have assumed that the repression of Ras signaling to the PRL promoter took place in the context of the composite FP IV monomer Pit-1/EBS site, required for optimal Ras signaling to the PRL promoter (Bradford et al. 1995, 1996, 1997, 2000). However, our results show that repression requires neither the FP IV nor EBS elements even in the presence of Ras (Fig. 4A and B). This decoupling of the promoter requirements for $\mathrm{R}$ as signaling and $\beta$-domain implies that repression is not due to alterations of interaction between Pit-1 and Ets-1.

A pattern emerges when we examine our results more closely. Both the promoter-specificity of repression and the DNA sequence requirements for repression of PRL promoter activity display a pattern of requirement for Pit-1 binding sites that transduce cAMP/PKA and growth factor signaling to the target promoter. The proximal $\mathrm{GH}$ promoter, which is repressed, contains a pair of elements that bind Pit-1 and allow Pit-1 tethering of activated CBP, while the proximal Pit-1 promoter, which is not repressed, binds Pit-1 as a monomer and contains two CREB-binding sites that themselves recruit CBP (Holloway et al. 1995, Gaiddon et al. 1996, Cohen et al. 1999) (Fig. 2).

The PRL promoter contains three elements that bind Pit-1 and transduce cAMP/PKA and growth factor signaling (FP I, II and III). The promoter also contains the FP IV Pit-1 monomer site that transduces Ras signaling (Nelson et al. 1988, Mangalam et al. 1989, Elsholtz et al. 1990, Voss et al. 1993, Kievit \& Maurer 2005). Our data show that mutant PRL promoters that lack FP I, FP II or FP III are not repressed. However, a mutant PRL promoter that lacks the FP IV site but retains the other sites is repressed. The results of the ChIP assays in Fig. 6 

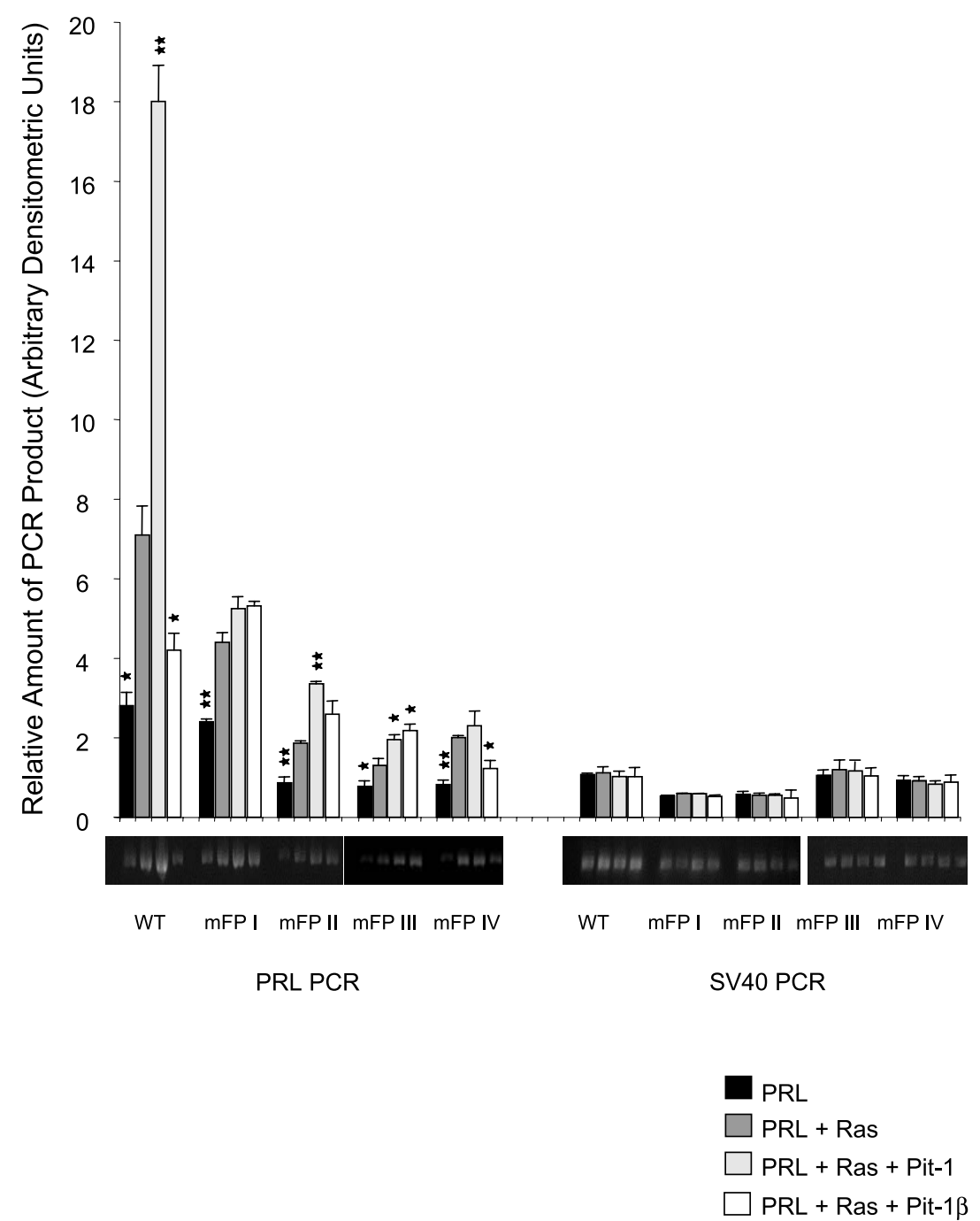

Figure 6 Pit- $1 \beta$ shows promoter-context requirements for alteration of the promoter acetylation state. Above, the effects of Pit- $1 \beta$ on histone acetylation of mutant PRL promoter by the Ras signaling pathway in $\mathrm{GH}_{3}$ cells. Three micrograms of plasmids $\mathrm{pA}_{3}$ PRLLuc ( - 425), $\mathrm{pA}_{3}$ PRLLuc( - 425)mFP I, $\mathrm{pA}_{3}$ PRLLuc( -425$) \mathrm{mFP}$ II, $\mathrm{pA}_{3}$ PRLLuc $(-425) \mathrm{mFP}$ III, $\mathrm{pA}_{3}$ PRLLuc $(-425) \mathrm{mFP}$ IV, or $\mathrm{pA}_{3} \mathrm{EBS}$, together with combinations of pSV Ras $(2 \mu \mathrm{g})$, pRSV HA Pit-1 $(10 \mu \mathrm{g})$, and pRSV HA Pit-1 $\beta(30 \mu \mathrm{g})$, were introduced into $4 \times 10^{6} \mathrm{GH}_{3}$ pituitary cells by electroporation, ten times for a total of $4 \times 10^{7}$ cells. After $24 \mathrm{~h}$, cells were harvested for ChIP assays (See Materials and Methods). Below, a representative ChIP assay is shown below the results of three ChIP experiments in triplicate, expressed as relative amounts of target and SV40 control promoter DNA associated with acetylated histone $\mathrm{H} 4$ (in arbitrary densitometric units) (See Materials and Methods). Starred bars are significantly different from vector+Ras: ${ }^{* *} P<0 \cdot 01 ;{ }^{*} P<0 \cdot 05$.

demonstrate that the DNA requirements for repression are the same as those for deacetylation of target promoters. The results of the ChIP assay for CBP recruitment (Fig. 7) demonstrate directly that Pit- $1 \beta$ reduces recruitment of $\mathrm{CBP}$ to the PRL and GH promoters, which recruit CBP through Pit-1, but has no negative effect on the Pit-1 promoter, which recruits CBP through CREB.
The requirement for multiple PRL Pit-1 binding sites for maximal gene activation in the pituitary, and for maximal repression by Pit- $1 \beta$, may reflect a requirement for multiple interactions to recruit CBP. Such a requirement has been shown for other genes such as the P31 element of the interferon-beta gene (Yang et al. 2002, 2003). The $\mathrm{GH}$ promoter also contains multiple 


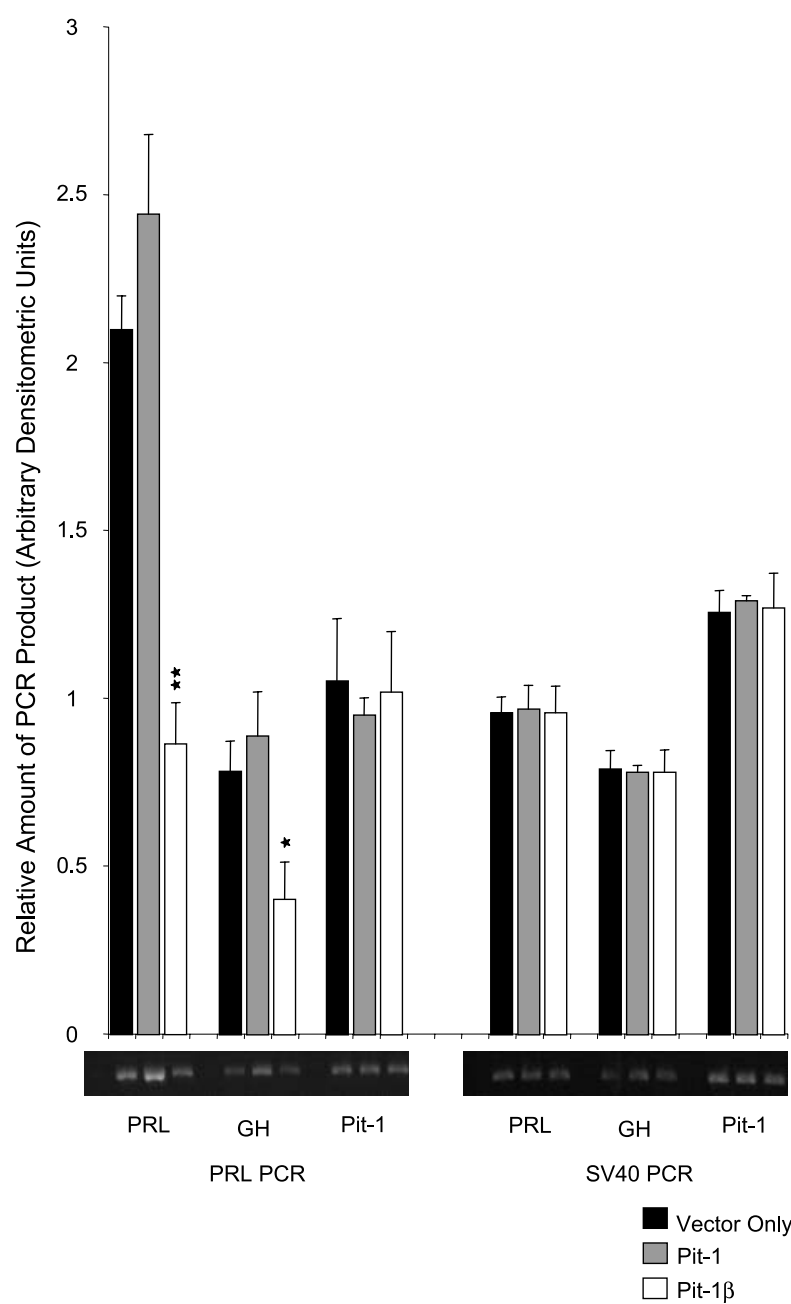

Figure 7 Pit- $1 \beta$ shows promoter-context requirements for reduction of $\mathrm{CBP}$ recruitment. Above, the effects of Pit-1 $\beta$ on CBP recruitment to PRL, GH and Pit-1 promoters by the Ras signaling pathway in $\mathrm{GH}_{3}$ cells. Three micrograms of plasmids pA3 PRL luc -425 , pA3 GH luc -593 or $\mathrm{pA}_{3}$ Pit-1 luc -200 , together with pSV40 and combinations of pRSV HA Pit-1 $(10 \mu \mathrm{g})$ and pRSV HA Pit-1 $\beta(30 \mu \mathrm{g})$, were introduced into $4 \times 10^{6} \mathrm{GH}_{3}$ pituitary cells by electroporation, ten times, for a total of $4 \times 10^{7}$ cells. After $24 \mathrm{~h}$, cells were harvested for ChIP assays (See Materials and Methods). Below, a representative ChIP assay is shown below the results of three ChIP experiments in triplicate, expressed as relative amounts of target and SV40 control promoter DNA associated with CBP (in arbitrary densitometric units) (See Materials and Methods). Starred bars are significantly different from vector only: ${ }^{* \star} P<0 \cdot 01$; ${ }^{*} P<0 \cdot 05$.

transcription factor binding sites. One, between the two Pit-1 sites, binds Zn-15/16, a Cys/His zinc-finger transcription factor that acts synergistically with Pit-1 to activate GH expression (Lipkin et al. 1993, Tuggle \& Trenkle 1996, Petersenn et al. 1997, Shewchuk et al. 1999, VanderHeyden et al. 2000).

We found that when FP I, FP II or FP III are altered, Pit-1 $\beta$ does not simply fail to repress the promoter, but instead it acts as an activator. We have shown previously that Pit-1 $\beta$ acts as an activator in non-pituitary cells (Diamond \& Gutierrez-Hartmann 1996, 2000, Diamond et al. 1999). It seems likely that Pit-1 can activate target promoters through two separate mechanisms, a pituitaryspecific mechanism dependent upon recruitment of CBP by Pit- 1 , which Pit- $1 \beta$ disrupts, and a second non-specific mechanism, independent of recruitment of CBP by Pit-1, for which Pit- $1 \beta$ is quite competent. Indeed, a mutant Pit-1 lacking the TAD, the location of the $\beta$-domain insertion, can alter PRL promoter nucleosome assembly but cannot activate transcription in a Xenopus laevis oocyte cell system (Kievit \& Maurer 2005). This suggests that the second, isoform-insensitive, mechanism of promoter activation seen in non-pituitary cells, may be due to chromatin alteration by Pit- 1 and Pit- $1 \beta$ that allows ubiquitous factors to bind and activate target promoters.

Thus, our findings support a model in which Pit-1 $\beta$ inhibits hormone gene expression by inhibiting Pit-1 recruitment of CBP to target promoters. Further experiments will investigate the physical mechanisms that underlie this inhibition.

\section{Acknowledgements}

The authors thank Ms Ashley Buckingham and Ms Cortney Stringer for technical assistance, Dr Dawn Duval for critical reading of this manuscript, other members of the Diamond and Gutierrez-Hartmann laboratories for their helpful suggestions and comments, and Dr Maria Cadwallader of The Editor Inc.com and Ms Dana Manning for careful proofreading.

\section{Funding}

S E D was supported by the American Cancer Society (RSG TBE-105036), the National Institutes of Health (K01 DK02752 and P20 RR15592) and the Kentucky Research Challenge Trust Fund. A G H was supported by the National Institutes of Health (R01 DK037667 and R01 DK046868). The authors declare that there is no conflict of interest that would prejudice the impartiality of this scientific work.

\section{References}

Augustijn KD, Duval DL, Wechselberger R, Kaptein R, Gutierrez-Hartmann A, van der Vliet PC 2002 Structural characterization of the PIT-1/ETS-1 interaction: PIT-1 phosphorylation regulates PIT-1/ETS-1 binding. PNAS 99 12657-12662.

Bradford AP, Conrad KE, Wasylyk C, Wasylyk B \& Gutierrez-Hartmann A 1995 Functional interaction of c-Ets-1 and GHF-1/Pit-1 mediates Ras activation of pituitary-specific gene expression: mapping of the essential c-Ets-1 domain. Molecular and Cellular Biology 15 2849-2857. 
Bradford AP, Conrad KE, Tran PH, Ostrowski MC \&

Gutierrrez-Hartmann A 1996 GHF-1/Pit-1 functions as a cell specific integrator of Ras signalling by targeting the Ras pathway to a composite Ets-1/GHF-1 response element. Journal of Biological Chemistry 271 24639-24648.

Bradford AP, Wasylyk C, Wasylyk B \& Gutierrez-Hartmann A 1997 Interaction of Ets-1 and the POU-homeodomain protein GHF-1/Pit-1 reconstitutes pituitary-specific gene expression. Molecular and Cellular Biology 17 1065-1074.

Bradford AP, Brodsky KS, Diamond SE, Kuhn LC, Liu Y \& Gutierrez-Hartmann A 2000 The Pit-1 homeodomain and beta-domain interact with Ets-1 and modulate synergistic activation of the rat prolactin promoter. Journal of Biological Chemistry $\mathbf{2 7 5}$ 3100-3106.

Camper SA, Yao YAS \& Rottman FM 1985 Hormonal regulation of the bovine prolactin promoter in rat pituitary tumor cells. Journal of Biological Chemistry 260 12246-12251.

Chen RP, Ingraham HA, Treacy MN, Albert VR, Wilson L \& Rosenfeld MG 1990 Autoregulation of Pit-1 gene expression mediated by two cis-active promoter elements. Nature 346 583-586.

Chu S, Mamers P, Burger HG \& Fuller PJ 2000 Estrogen receptor isoform gene expression in ovarian stromal and epithelial tumors. Journal of Clinical Endocrinology and Metabolism 85 1200-1205.

Cohen LE, Hashimoto Y, Zanger K, Wondisford F \& Radovick S 1999 CREB-independent regulation by CBP is a novel mechanism of human growth hormone gene expression. Journal of Clinical Investigation 104 1123-1130.

Conrad KE \& Gutierrez-Hartmann A 1992 The ras and protein kinase A pathways are mutually antagonistic in regulating rat prolactin promoter activity. Oncogene 7 1279-1286.

Conrad KE, Oberwetter JM, Vallaincourt R, Johnson GL \& Gutierrez-Hartmann A 1994 Identification of the functional components of the Ras signaling pathway regulating pituitary cell-specific gene expression. Molecular and Cellular Biology $\mathbf{1 4}$ 1553-1565.

Delhase M, Vila V, Hooghe-Peters EL \& Castrillo JL 1995 A novel pituitary transcription factor is produced by alternative splicing of the human GHF-1/Pit-1 gene. Gene 155 273-275.

Diamond SE \& Gutierrez-Hartmann A 1996 A 26-amino acid insertion domain defines a functional transcription switch motif in Pit-1 beta. Journal of Biological Chemistry 271 28925-28932.

Diamond SE \& Gutierrez-Hartmann A 2000 The Pit-1ß-domain dictates active repression and alteration of histone acetylation of the proximal prolactin promoter. Journal of Biological Chemistry $\mathbf{2 7 5}$ 30977-30986.

Diamond SE, Chiono M \& Gutierrez-Hartmann A 1999 Reconstitution of the protein kinase A response of the rat prolactin promoter: differential effects of distinct Pit-1 isoforms and functional interaction with Oct-1. Molecular Endocrinology 13 228-238.

Dolle P, Castrillo JL, Theill LE, Deerinck T, Ellisman M \& Karin M 1990 Expression of GHF-1 protein in mouse pituitaries correlates both temporally and spatially with the onset of growth hormone gene activity. Cell 60 809-820.

Duval DL, Jean A \& Gutierrez-Hartmann A 2003 Ras signaling and transcriptional synergy at a flexible Ets-1/Pit-1 composite DNA element is defined by the assembly of selective activation domains. Journal of Biological Chemistry 278 39684-39696.

Eckel KL, Tentler JJ, Cappetta GJ, Diamond SE \& Gutierrez-Hartmann A 2003 The epithelial-specific ETS transcription factor ESX/ESE-1/Elf-3 modulates breast cancer-associated gene expression. DNA Cell Biology 22 79-94.

Elsholtz HP 1992 Molecular biology of prolactin: cell-specific and endocrine regulators of the prolactin gene. Seminars in Reproductive Endocrinology 10 183-195.

Elsholtz HP, Albert VR, Treacy MN \& Rosenfeld MG 1990 A two-base change in a POU factor-binding site switches pituitary-specific to lymphoid-specific gene expression. Genes and Development 4 43-51.
Fischberg DJ, Chen XH \& Bancroft C 1994 A Pit-1 phosphorylation mutant can mediate both basal and induced prolactin and growth hormone promoter activity. Molecular Endocrinology 8 1566-1573.

Fliss MS, Hinkle PM \& Bancroft C 1999 Expression cloning and characterization of PREB (prolactin regulatory element binding), a novel WD motif DNA-binding protein with a capacity to regulate prolactin promoter activity. Molecular Endocrinology 13 644-657.

Flug F, Copp RP, Casanova J, Horowitz ZD, Janocko L, Plotnick M \& Samuels HH 1987 Cis-acting elements of the rat growth hormone gene which mediate basal and regulated expression by thyroid hormone. Journal of Biological Chemistry 262 6373-6382.

Gaiddon C, Tian J, Loeffler JP \& Bancroft C 1996 Constitutively active $G(S)$ alpha-subunits stimulate Pit-1 promoter activity via a protein kinase A-mediated pathway acting through deoxyribonucleic acid binding sites both for Pit-1 and for adenosine $3^{\prime}, 5^{\prime}$-monophosphate response element-binding protein. Endocrinology 137 1286-1291.

Gutierrez-Hartmann A, Siddiqui S \& Loukin S 1987 Selective transcription and DNase I protection of the rat prolactin gene by GH3 pituitary cell-free extracts. PNAS 84 5211-5215.

Haugen BR, Gordon DF, Wood WW \& Ridgway EC 1994 The combination of Pit-1 and Pit-1T have a synergistic stimulatory effect on the thyrotropin $B$ subunit promoter but not the growth hormone or prolactin promoters. Molecular Endocrinology 8 1574-1582.

Holloway J, Szeto D, Scully K, Glass C \& Rosenfeld M 1995 Pit-1 binding to specific DNA sites as a monomer of dimer determines gene-specific use of a tyrosine-dependent synergy domain. Genes and Development 9 1992-2006.

Howard PW \& Maurer RA 1994 Thyrotropin releasing hormone stimulates transient phosphorylation of the tissue-specific transcription factor, Pit-1. Journal of Biological Chemistry 269 28662-28669.

Huguier S, Baguet J, Perez S, van Dam H, Castellazzi M 1998 Transcription factor ATF2 cooperates with v-Jun to promote growth factor-independent proliferation in vitro and tumor formation in vivo. Molecular and Cellular Biology 18 7020-7029.

Jackson SM, Keech CA, Williamson DJ \& Gutierrez-Hartmann A 1992 Interaction of positive and negative transcription elements controls repression of the proximal rat prolactin promoter in nonpituitary cells. Molecular and Cellular Biology 12 2708-2719.

Jurdic P, Treilleux I, Vandel L, Tabone E, Huguier S, Sergeant A \& Castellazzi M 1995 Tumor induction by v-Jun homodimers in chickens. Oncogene 11 1699-1709.

Keech CA, Jackson SM, Siddiqui SK, Ocran KW \& Gutierrez-Hartmann A 1992 Cyclic adenosine 3',5'-monophosphate activation of the rat prolactin promoter is restricted to the pituitary-specific cell type. Molecular Endocrinology 6 2059-2070.

Kievit P \& Maurer RA 2005 The pituitary-specific transcription factor, Pit-1, can direct changes in the chromatin structure of the prolactin promoter. Molecular Endocrinology. 19 138-147.

Konzak KE \& Moore DD 1992 Functional isoforms of Pit-1 generated by alternative mRNA splicing. Molecular Endocrinology 6 241-247.

Lambert JR \& Nordeen SK 2003 CBP Recruitment and histone acetylation in differential gene induction by glucocorticoids and progestins. Molecular Endocrinology 17 1085-1094.

Lefstin JA \& Yamamoto KR 1998 Allosteric effects of DNA on transcriptional regulators. Nature $392885-888$.

Liang J, Kim KE, Schoderbeck WE \& Maurer RA 1992 Characterization of a nontissue-specific, $3^{\prime}, 5^{\prime}$-cyclic adenosine monophosphate-responsive element of the proximal region of the rat prolactin gene. Molecular Endocrinology 6 885-892.

Lipkin SM, Naar AM, Kalla KA, Sack RA \& Rosenfeld MG 1993 Identification of a novel zinc finger protein binding a conserved element critical for Pit-1-dependent growth hormone gene expression. Genes and Development 7 1674-1687. 
Longui CA, Vottero A, Adamson PC, Cole DE, Kino T, Monte O \& Chrousos GP 2000 Low glucocorticoid receptor alpha/beta ratio in T-cell lymphoblastic leukemia. Hormone and Metabolic Research 32 401-406.

Mangalam HJ, Albert VR, Ingraham HA, Kapiloff M, Wilson L, Nelson C, Elsholtz H, Rosenfeld MG 1989 A pituitary POU domain protein, Pit-1, activates both growth hormone and prolactin promoters transcriptionally. Genes and Development 3 946-958.

Maxwell IH, Harrison GS, Wood WM \& Maxwell F 1989 A DNA cassette containing a trimerized SV40 polyadenylation signal which efficiently blocks spurious plasmid-initiated transcription. Biotechniques 7 276-280.

McCormick A, Brady H, Theill LE \& Karin M 1990 Regulation of the pituitary-specific homeobox gene GHF1 by cell-autonomous and environmental cues. Nature 345 829-832.

McCormick A, Brady H, Fukushima J \& Karin M 1991 The pituitary-specific regulatory gene GHF1 contains a minimal cell type-specific promoter centered around its TATA box. Genes and Development 5 1490-1503.

McGowan EM \& Clarke CL 1999 Effect of overexpression of progesterone receptor A on endogenous progestin-sensitive endpoints in breast cancer cells. Molecular Endocrinology 13 $1657-1671$

Morris AE, Kloss B, McChesney RE, Bancroft C \& Chasin LA 1992 An alternatively spliced Pit-1 isoform altered in its ability to trans-activate. Nucleic Acids Research 20 1355-1361.

Nelson C, Albert VR, Elsholtz HP, Lu LI-W \& Rosenfeld MG 1988 Activation of cell-specific expression of rat growth hormone and prolactin genes by a common transcription factor. Science $\mathbf{2 3 9}$ 1400-1405.

Okimura Y, Howard PW \& Maurer RA 1994 Pit-1 binding sites mediate transcriptional responses to cAMP through a mechanism which does not require inducible phosphorylation of Pit-1. Molecular Endocrinology 8 1559-1565.

Ono M \& Takayama Y 1992 Structures of cDNAs encoding chum salmon pituitary-specific transcription factor, Pit-1/GHF-1. Gene $116275-279$

Palomino T, Barettino D \& Aranda A 1998 Role of GHF-1 in the regulation of the rat growth hormone gene promoter by thyroid hormone and retinoic acid receptors. Journal of Biological Chemistry 273 27541-27547.

Petersenn S, Maaser C \& Schulte HM 1997 Transcriptional activation of the human growth hormone gene by ras oncogene. Molecular and Cellular Endocrinology 129 47-54.

Pickett CA \& Gutierrez-Hartmann A 1997 In Molecular and Cellular Ontogeny of Distinct Pituitary Cell Types, ch. 3 edn 3, pp 1-31. Ed. ME Wierman. Totowa, NY: Humana Press, Inc.

Rajnarayan S, Chiono M, Alexander LM \& Gutierrez-Hartmann A 1995 Reconstitution of protein kinase A regulation of the rat prolactin promoter in HeLa nonpituitary cells: identification of both GHF-1/Pit-1-dependent and -independent mechanisms. Molecular Endocrinology 9 502-512.

Richer JK, Lange CA, Wierman AM, Brooks KM, Tung L, Takimoto GS \& Horwitz KB 1998 Progesterone receptor variants found in breast cells repress transcription by wild-type receptors. Breast Cancer Research and Treatment 48 231-241.

Ryan AK \& Rosenfeld MG 1997 POU domain family values: flexibility, partnerships and developmental codes. Genes and Development 11 1207-1225.

Schaufele F 1996 CCAAT/enhancer-binding protein alpha activation of the rat growth hormone promoter in pituitary progenitor GHFT1-5 cells. Journal of Biological Chemistry 271 21484-21489.

Scully KM, Jacobson EM, Jepsen K, Lunyak V, Viadiu H, Carriere C, Rose DW, Hooshmand F, Aggarwal AK \& Rosenfeld MG 2000 Allosteric effects of pit-1 DNA sites on long-term repression in cell type specification. Science 290 1127-1131.
Shewchuk BM, Asa SL, Cooke NE \& Liebhaber SA 1999 Pit-1 binding sites at the somatotrope-specific DNase I hypersensitive sites I, II of the human growth hormone locus control region are essential for in vivo hGH-N gene activation. Journal of Biological Chemistry 274 35725-35733.

Simmons DM, Voss JW, Ingraham HA, Holloway JM, Broide RS, Rosenfeld MG \& Swanson LW 1990 Pituitary cell phenotypes involve cell-specific Pit-1 mRNA translation and synergistic interactions with other classes of transcription factors. Genes and Development 4 695-711.

Tabakin-Fix Y, Huleihel M \& Aboud M 2004 Activation of simian virus 40 promoter by HTLV-I Tax protein: role of NF-kappaB and CBP. Biochemical and Biophysical Research Communications 318 1052-1056.

Tashjian AHJ, Yasumura Y, Levine L, Sato GH \& Parker ML 1968 Establishment of clonal strains of rat pituitary tumor cells that secrete growth hormone. Endocrinology 82 342-352.

Theill LE, Hattori K, Domenico D, Castrillo JL \& Karin M 1992 Differential splicing of the GHF1 primary transcript gives rise to two functionally distinct homeodomain proteins. EMBO Journal 11 2261-2269.

Tokitou F, Nomura T, Khan MM, Kaul SC, Wadhwa R, Yasukawa T, Kohno I \& Ishii S 1999 Viral ski inhibits retinoblastoma protein $(\mathrm{Rb})$-mediated transcriptional repression in a dominant negative fashion. Journal of Biological Chemistry 274 4485-4488.

Treier M \& Rosenfeld M 1996 The hypothalamic-pituitary axis: co-development of two organs. Current Opinion in Cell Biology $\mathbf{8}$ 833-843.

Tuggle CK \& Trenkle A 1996 Control of growth hormone synthesis. Domestic Animal Endocrinology 13 1-33.

VanderHeyden TC, Wojtkiewicz PW, Voss TC, Mangin TM, Harrelson Z, Ahlers KM, Phelps CJ \& Hurley DL 2000 Mouse growth hormone transcription factor $\mathrm{Zn}-16$ : unique bipartite structure containing tandemly repeated zinc finger domains not reported in rat $\mathrm{Zn}-15$. Molecular and Cellular Endocrinology 159 89-98.

Voss JW, Wilson L, Rhodes SJ \& Rosenfeld MG 1993 An alternative Pit-1 RNA splicing product reveals modular binding and nonmodular transcriptional activities of the POU-specific domain. Molecular Endocrinology 7 1551-1560.

Wong EA, Silsby JL, El Halawani ME 1992 Complementary DNA cloning and expression of Pit-1/GHF-1 from the domestic turkey. DNA and Cell Biology 11 651-660.

Wood WM, Dowding JM, Bright TM, McDermott MT, Haugen BR, Gordon DF \& Ridgway EC 1996 Thyroid hormone receptor beta2 promoter activity in pituitary cells is regulated by Pit-1. Journal of Biological Chemistry 271 24213-24220.

Xu L, Lavinsky RM, Dasen JS, Flynn SE, McInerney EM, Mullen TM, Heinzel T, Szeto D, Korzus E, Kurokawa R et al. 1998 Signal-specific co-activator domain requirements for Pit-1 activation. Nature 395 301-306.

Yang H, Lin CH, Ma G, Orr M, Baffi MO \& Wathelet MG 2002 Transcriptional activity of interferon regulatory factor (IRF)-3 depends on multiple protein-protein interactions. European Journal of Biochemistry $2696142-6151$.

Yang H, Lin CH, Ma G, Baffi MO \& Wathelet MG 2003 Interferon regulatory factor-7 synergizes with other transcription factors through multiple interactions with p300/CBP coactivators. Journal of Biological Chemistry 278 15495-15504.

Ye ZS, Forman BM, Aranda A, Pascual A, Park HY, Casanova J \& Samuels HH 1988 Rat growth hormone gene expression. Both cell-specific and thyroid hormone response elements are required for thyroid hormone regulation. Journal of Biological Chemistry 263 $7821-7829$.

Received 11 October 2004

Accepted 6 January 2005 